\title{
AMINO NITROGEN CHANGES OF THE BLOOD IN NEPHRITIS
}

\author{
BY ESBEN KIRK \\ (From the Hospital of the Rockefeller Institute for Medical Research, New York City)
}

(Received for publication July 25, 1933)

Amino nitrogen and peptide nitrogen content of the blood in nephritic patients have been frequently determined since the introduction of suitable micro methods. Gasometric determinations of amino nitrogen and peptide nitrogen of plasma and red blood cells separately have, however, not yet been done.

That colorimetric analyses of the same blood samples give lower results for amino acid nitrogen than the gasometric method or the formaldehyde titration, and that colorimetric recovery of amino acids added to blood is incomplete, have been reported by Van Slyke and Kirk (18). The use of different analytical methods may accordingly explain the conflicting results reported in the literature. Thus most observers using the colorimetric method of Folin (Berglund (2), Greene, Sandiford and Ross (6), Schmidt (16), Witts (20), Feinblatt and Shapiro (5)) found no deviation from the normal in series of patients with nephritis, including several cases of uremia. Slightly or moderately increased values of amino nitrogen in uremia were reported with the colorimetric method by Wowsi and Gelbird (21), and by Looney (11) in an individual case of mercuric chloride poisoning shortly before death. Extensive studies have been made in recent years in Volhard's clinic by Becher and Herrmann (1) with a modification of Folin's colorimetric technique; increase of free amino nitrogen of whole blood was frequently observed in patients with severe impairment of the kidney function. Only in a single case, however, did the method used indicate values exceeding 10 milligrams per cent.

Most of the work done with the gasometric method is of earlier date. Using various protein precipitants Bock (3), Okada and Hayashi (14), and Desqueyroux (4), all found increased amino nitrogen of the blood in cases of advanced nephritis. In nephritic toxemias of pregnancy, on the other hand, Losee and Van Slyke (12), and Morse (13) observed no marked deviation from the normal.

Quantitative determination of peptide nitrogen of blood was first made with exact methods by Hiller and Van Slyke in 1922 (7) by gasometric determination of blood filtrates before and after hydrolysis with hydrochloric acid. A similar procedure of acid hydrolysis has been used by different authors in studies of the peptide nitrogen in nephritis, 
but in most cases other methods were substituted for the gasometric to determine the amino nitrogen before and after hydrolysis. When comparing results both the method of amino nitrogen determination and the protein precipitant used should be considered. Hülse and Strauss (9), using the formaldehyde titration method of Sørensen, and Hülse and Franke (8), using the gasometric method, observed high values for peptide nitrogen in nephritic patients with hypertension. Jackson, Sherwood and Moore (10), Becher and Herrmann (1), and Schlossmann (15), using the colorimetric method, were, however, unable to find any relation between the blood pressure and the content of peptide nitrogen in the blood in nephritis. A definite increase in peptide nitrogen was frequently seen by Becher and Herrmann (1) in cases of severe renal insufficiency, the peptide nitrogen even occasionally exceeding the concentration of free amino nitrogen; increase of peptide nitrogen with normal amino nitrogen values was sometimes observed.

\section{METHODS}

For separate analyses of cells and plasma, oxalated blood was centrifuged till constant volume of the red blood cells was obtained; plasma was then syphoned off and the intermediate layer of plasma and cells discarded. Samples of red blood cells were measured with a calibrated pipette "to contain."

Urea was transformed into ammonia by addition of a urease solution and phosphate buffer as described by Van Slyke (17). The proteins of plasma or whole blood were then precipitated by the Folin-Wu method. To plasma or whole blood one volume of 10 per cent sodium tungstate and one volume of $2 / 3 \mathrm{~N}$ sulfuric acid were added, and the mixture was diluted with water to 10 times the original volume of the sample. For precipitation of the proteins of the red blood corpuscles two volumes of 10 per cent sodium tungstate and two volumes of $2 / 3 \mathrm{~N}$ sulfuric acid were used for each volume of cells, but the sample was finally, as in precipitation of plasma and whole blood, made up to 10 times its original volume with water. Five cc. of filtrate, therefore, represented $0.5 \mathrm{cc}$. of plasma, red blood corpuscles or whole blood. Usually, however, the filtrate from the red blood corpuscles was again diluted with two volumes of distilled water to obtain sufficient material for analysis. Because of the high amino nitrogen content of the red blood cells the dilution did not diminish the amino nitrogen readings enough to interfere with accuracy.

The ammonia of the filtrates, formed by the splitting of the urea with urease, was removed by boiling with milk of magnesia and amino nitrogen afterwards determined by the manometric method of Van Slyke (17).

For determination of peptide nitrogen the urea-and-ammonia-free filtrates were heated on a water bath for 24 hours with equal volumes of concentrated hydrochloric acid. After evaporation of the acid in an open dish each residue was neutralized with a few drops of a saturated solution of sodium acetate and finally made up to volume (7). It was found unnecessary to subject the hydrolyzed samples again to boiling with milk of magnesia before the amino acid determination, as identical results were obtained with and without such treatment.

For blank analyses a urease solution was prepared, and precipitated, and 
the filtrate was diluted as described by Van Slyke (17, p. 442), or Peters and Van Slyke (22). The amino nitrogen content of the filtrate was determined before and after hydrolysis, to obtain the $c$. correction. Separate blanks were determined for analyses of plasma and red blood corpuscles.

The normal magnitude and constancy of results obtained with the above procedure is illustrated by Table I. It gives the results from two samples of the same blood which were centrifuged and analysed separately. The sample of plasma filtrate represented $0.5 \mathrm{cc}$. of plasma, the sample of filtrate of red blood cells 0.167 cc. of corpuscles.

TABLE I

\section{Showing reproducibility of measurements}

Milligrams per cent amino nitrogen

I

Plasma, unhydrolyzed

4.10

Plasma, hydrolyzed......... 4.10

4.07

R.B.C., unhydrolyzed . . . . . . . 12.85

R.B.C., hydrolyzed.......... 18.89

Studies of amino nitrogen and peptide nitrogen of the blood were made in seven uremic patients. (See Tables II and III.)

TABLE II

Amino nitrogen in whole blood during development of uremic coma Case No. 1, M.J. Hospital No. 7855

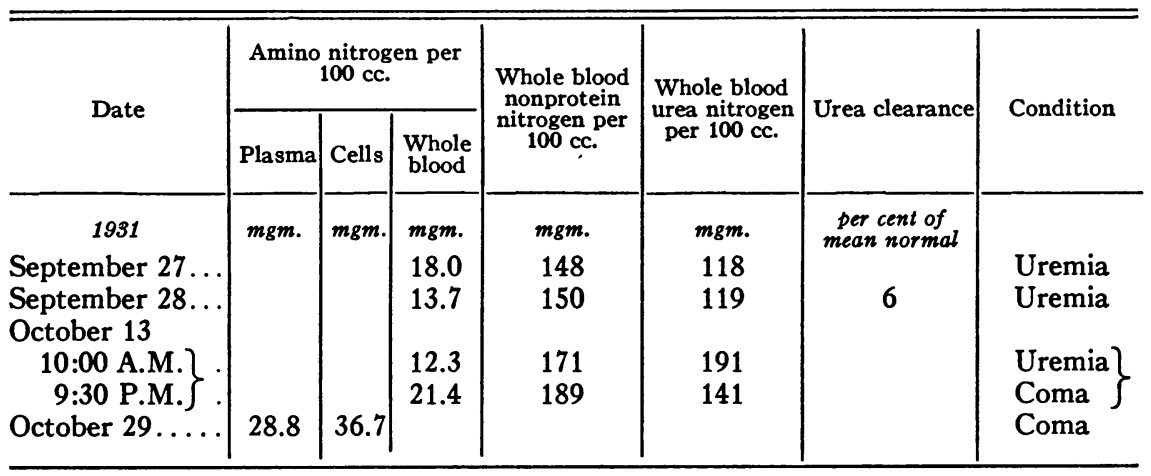

\section{CLINICAL NOTES ON UREMIC CASES ${ }^{1}$}

Case No. 1. Hospital No. 7855. M. J., female, 33 years. As a child had

1 The nomenclature followed here for the different types and stages of Bright's disease is in general that used by Van Slyke, Stillman, et al. (19). In addition, to distinguish the different conditions near and in coma, the following terms are used:

Terminal stage with nitrogen retention. Nitrogen retention without clinical symptoms.

Uremia. Nitrogen retention with clinical symptoms, such as nausea and vomiting, but with normal consciousness.

Semi-comatose condition. Consciousness greatly influenced, but patient still responds.

Coma. Patient unconscious and does not respond. 


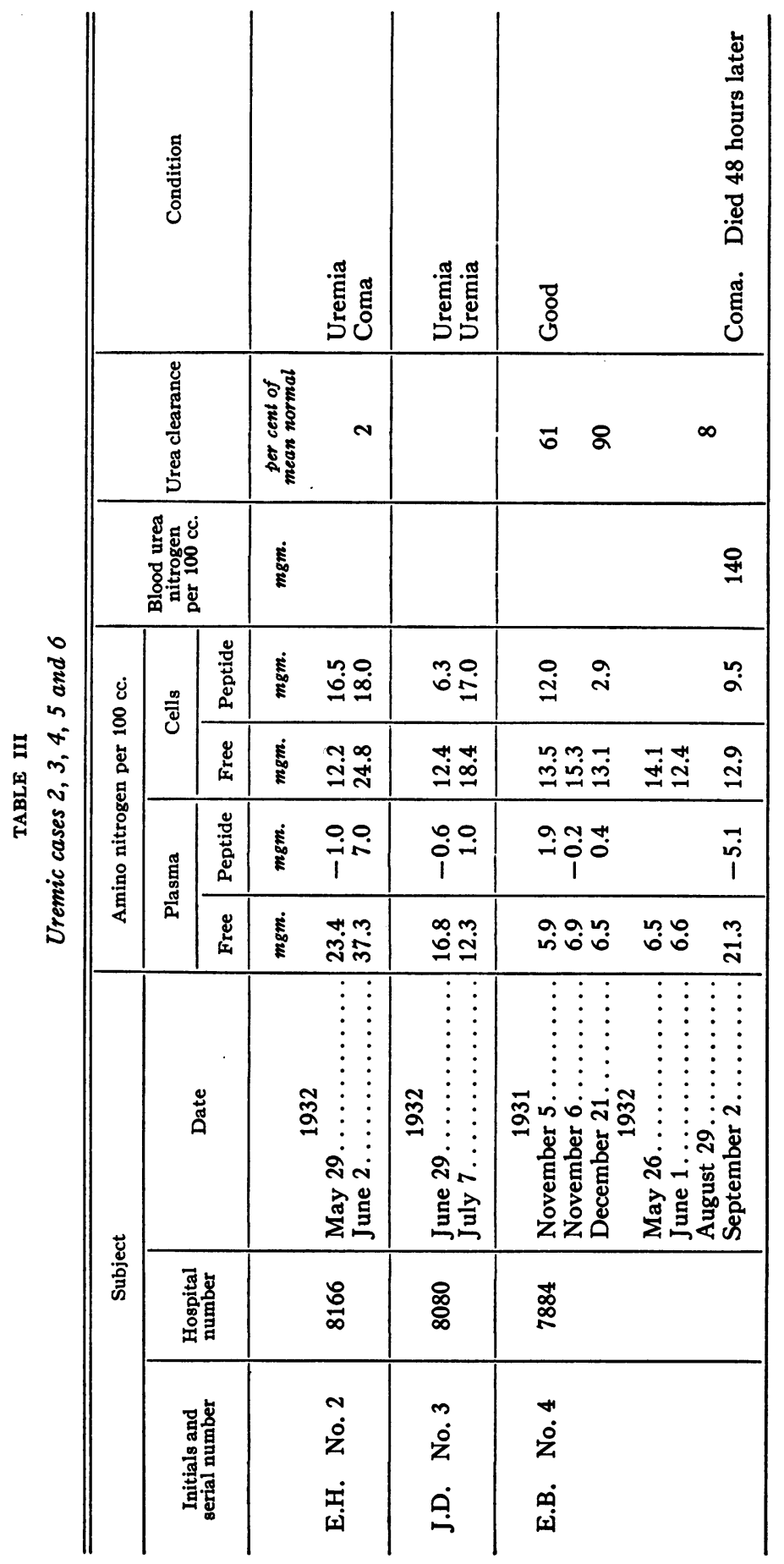


ESBEN KIRK

1095

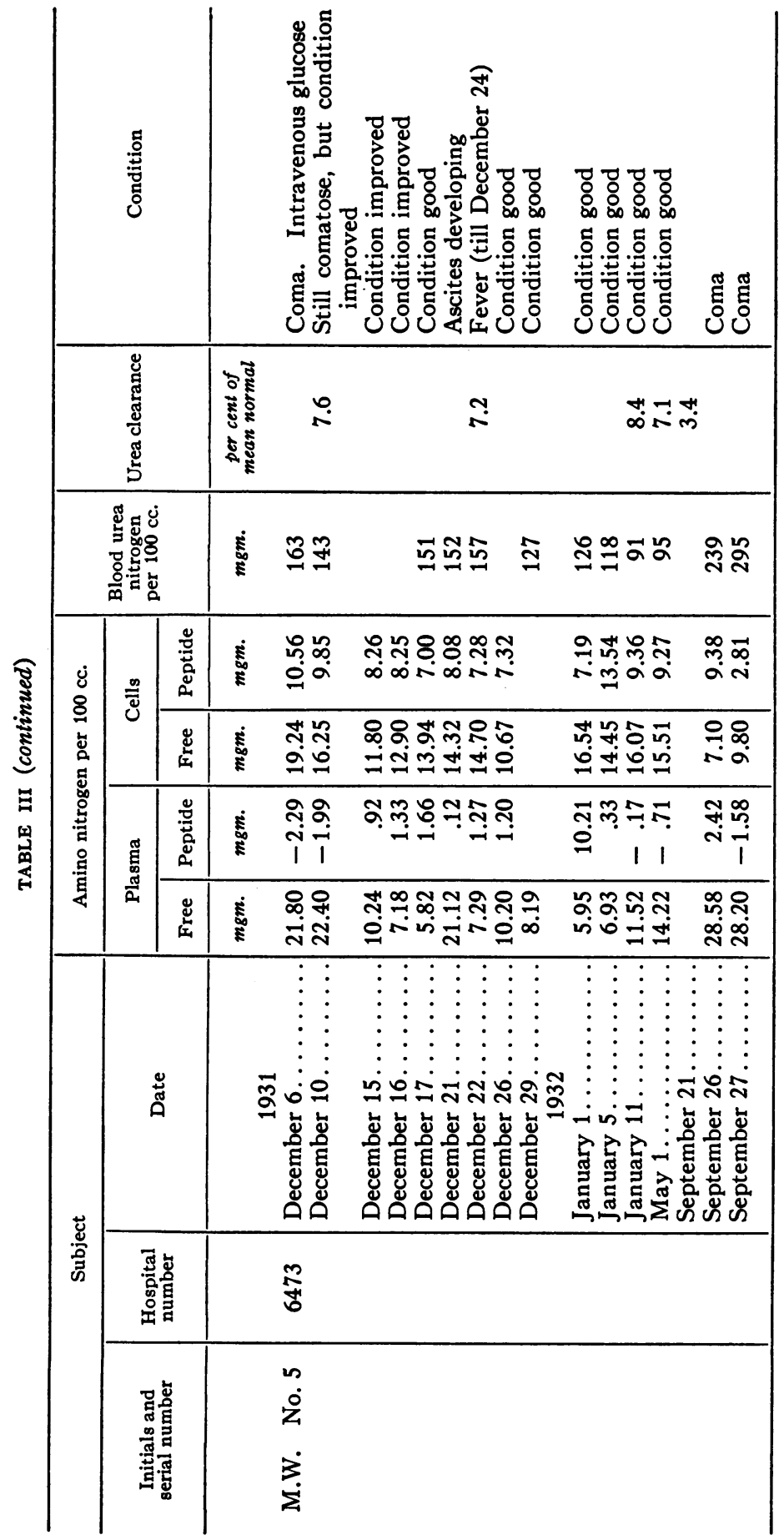




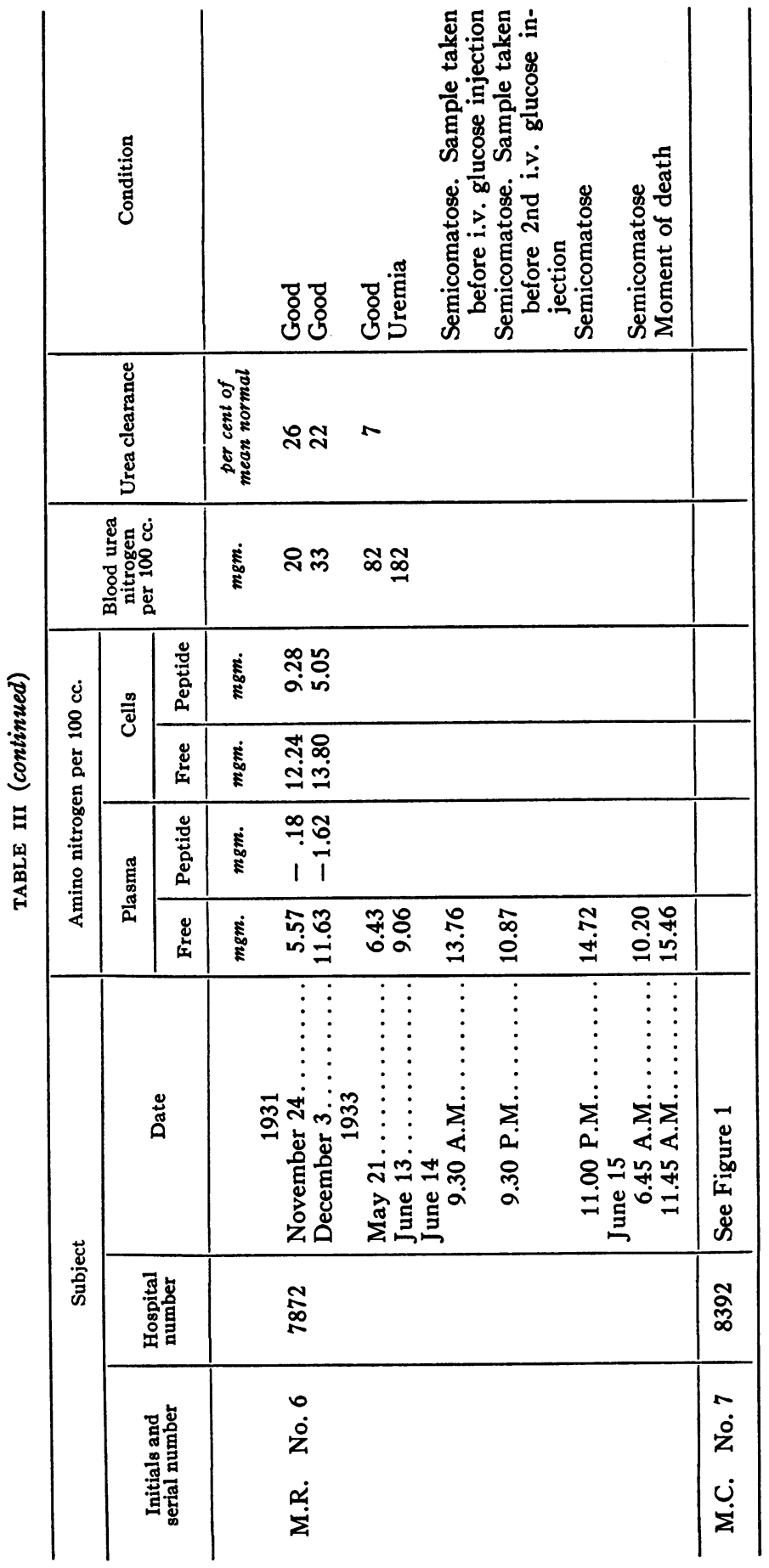


hemorrhagic Bright's disease following tonsillitis. After several years of active symptoms the patient went into a latent stage, but the renal lesion became active again during a pregnancy, necessitating abortion. In the following period of ten years exhibited hypertension and proteinuria. Two weeks before admission vomiting, edema of feet and dyspnea developed. On admission (September 25, 1931) was in uremia.

Case No. 2. Hospital No. 8166. E. H., female, 21 years. Two years before admission had hematuria and hypertension. Visual disturbances, edema of ankles, vomiting and diarrhea had been present in the last weeks. On admission (May 28, 1932) was in uremia.

Case No. 3. Hospital No. 8080. J. D., male, 30 years. Ten months before admission developed tonsillitis, proteinuria and hypertension, followed by edema and ascites. In the last days had had severe nose bleedings. On admission (June 28, 1932) was in uremia.

Case No. 4. Hospital No. 7884. E. B., male, 29 years. Nine years before admission had had respiratory infection with hematuria. Recovered into a latent stage with proteinuria as only symptom. In the last six months had had hypertension and severe headache. The patient was observed for several months during the chronic active stage, and during the last weeks of terminal uremia.

Case No. 5. Hospital No. 6473. M. W., male, 15 years. Three and a half years before admission developed generalized edema with proteinuria and reduced kidney function following an attack of upper respiratory infection. In the following period gave evidence of activity in the kidney lesion (microscopic hematuria). Immediately before admission (December 3, 1931) suffered from abnormal sleepiness and attacks of convulsions.

Case No. 6. Hospital No. 7872. M. R., female, 19 years. Four months before first admission had edema of the legs. On admission (October 21, 1931) macroscopic hematuria, hypertension and reduced kidney function were present. In the following 18 months the nephritis progressed through the chronic active to the terminal stage. Two weeks before last admission (May 4, 1933) reduction of vision and occasional cardiac decompensation were noted. Death occurred on June 15,1933 , after two days of a semicomatose condition.

Case No. 7. Hospital No. 8342. M. C., male, 19 years. Four years before admission developed proteinuria (and hematuria ?) following mastoiditis. Went into a latent stage of hemorrhagic Bright's disease. Three weeks before admission had had inflammation of the mandibular region, caused by hemolytic streptococci. In relation to this infection there occurred acute exacerbation of the nephritis with oliguria, gross nitrogen retention and vomiting. On admission (November 25, 1932) was in acute uremia, markedly dehydrated. During the first days in the hospital was at intervals extremely drowsy, but not comatose.

Following treatment of the dehydration the patient made a quick recovery to an excellent general condition. The activity of the renal lesion persisted, however, and the kidney function never exceeded 10 per cent of the average normal urea clearance.

Amino nitrogen determinations of plasma were made daily for a period of about three months. The data are presented in Figure 1. The highest value, $38.7 \mathrm{mgm}$. of amino nitrogen per $100 \mathrm{cc}$. of plasma, was observed on November 29,1932 , at a time when the patient was very drowsy. 


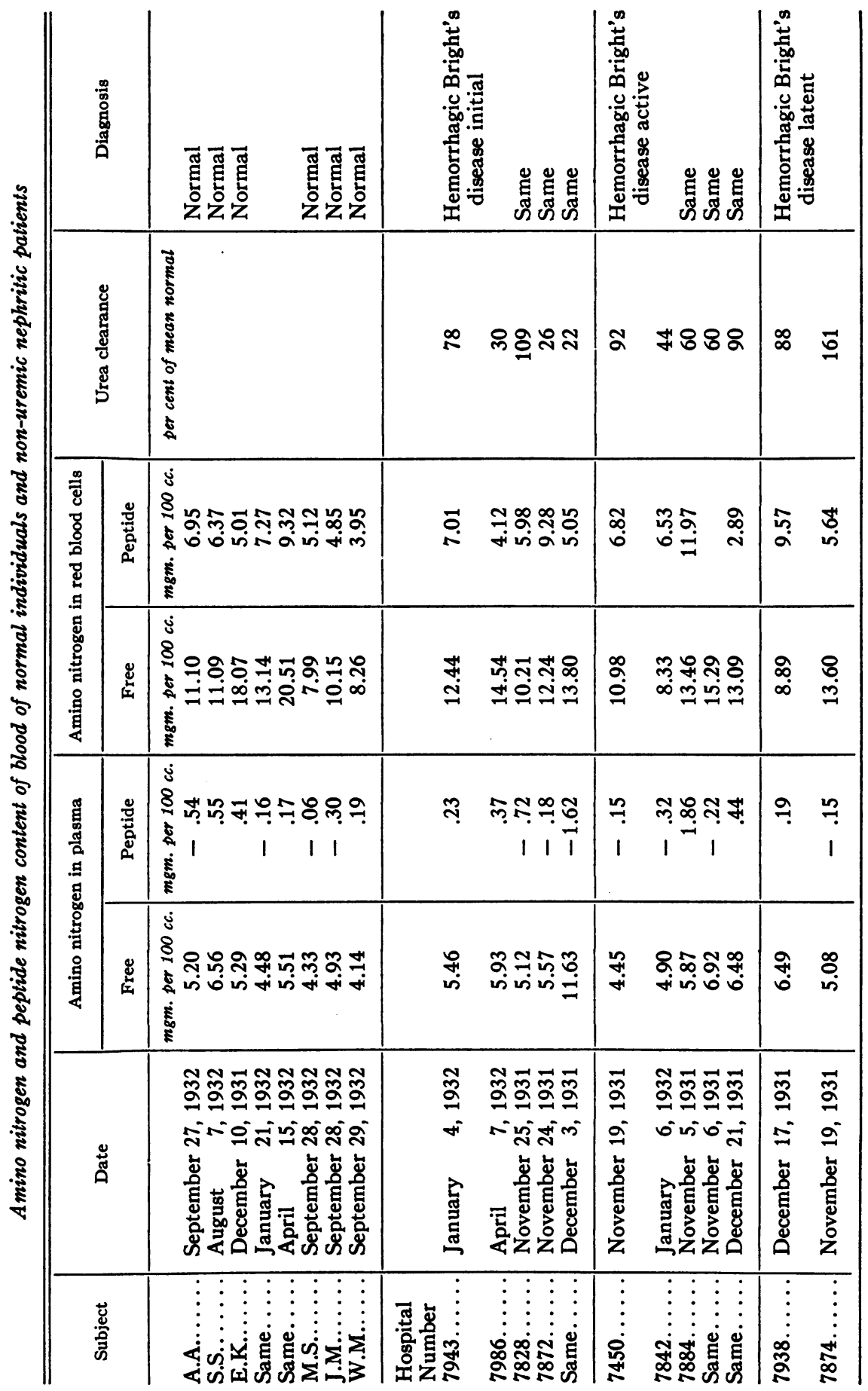




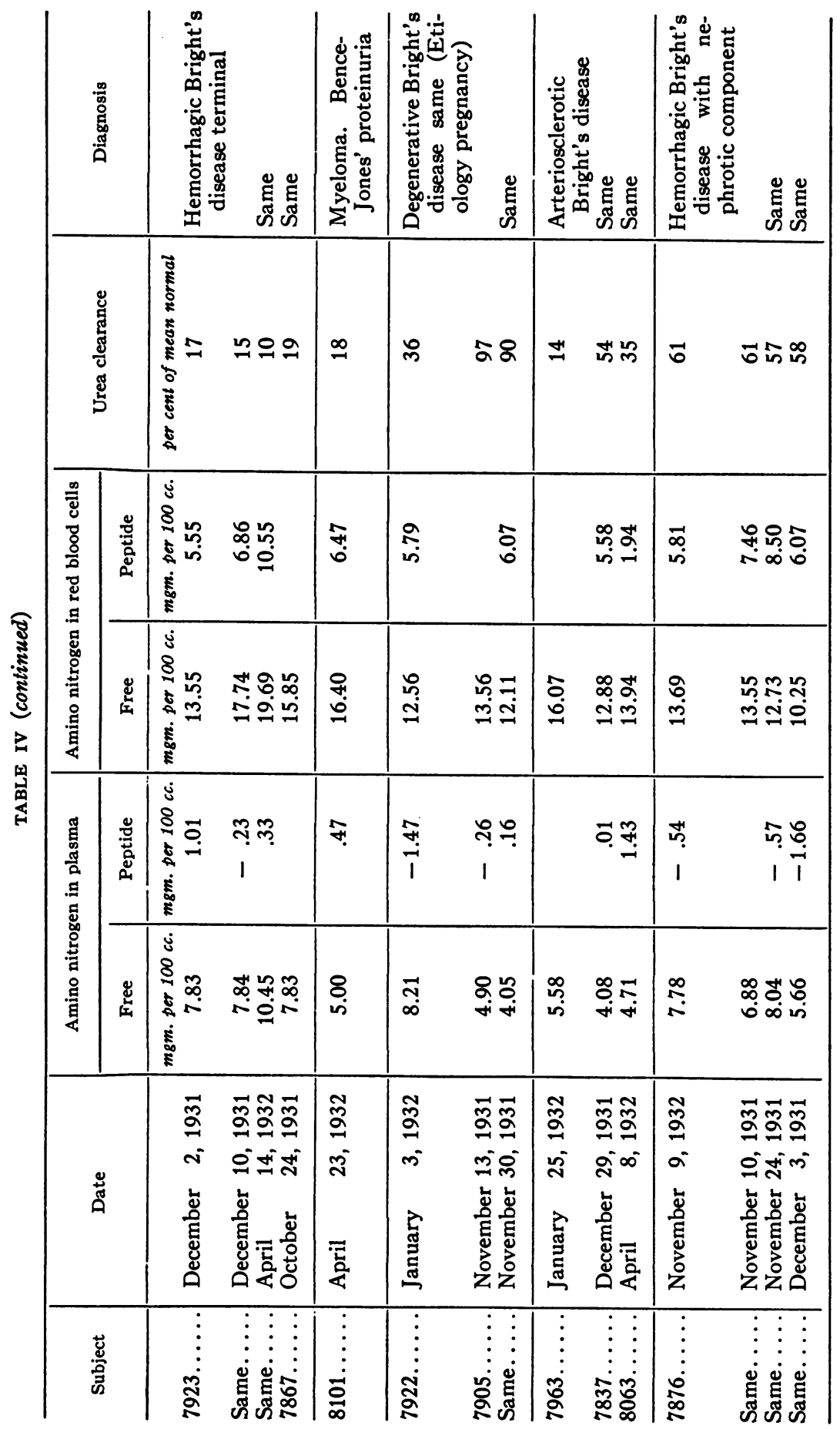




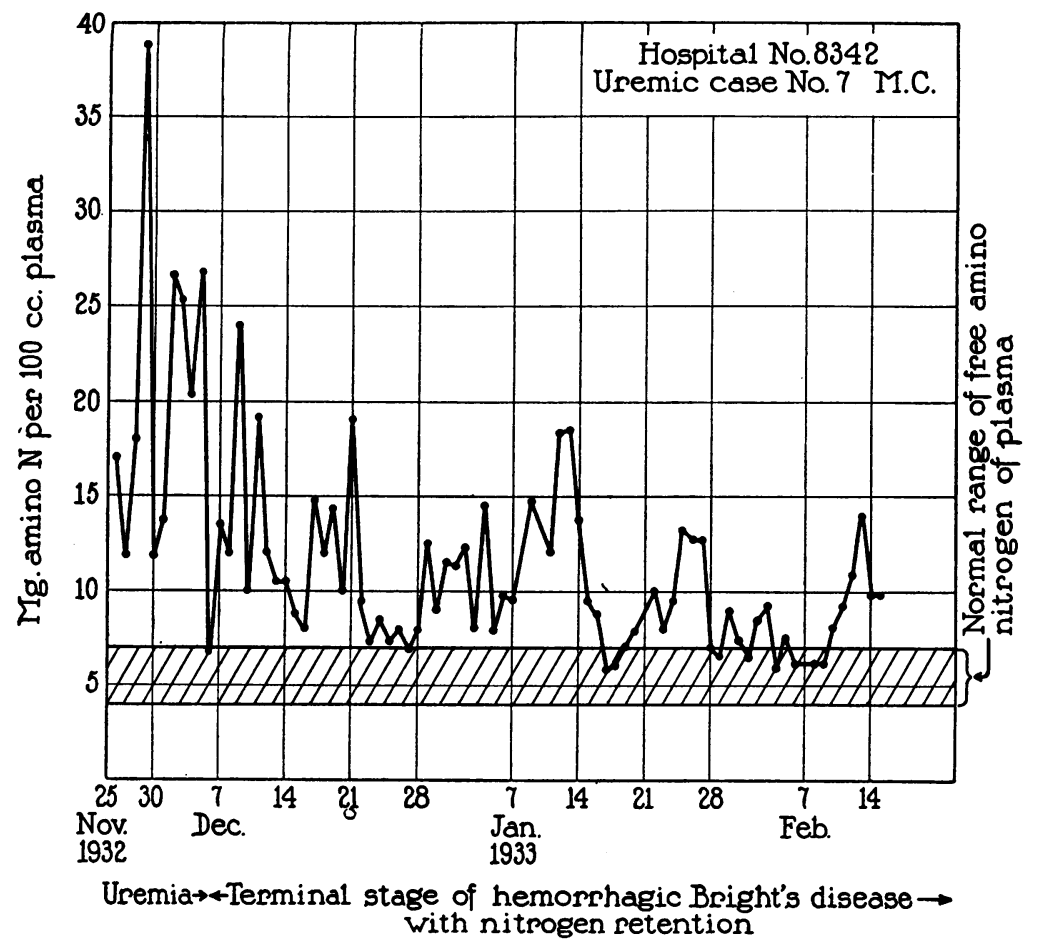

Fig. 1. Amino Nitrogen Content of Blood Plasma During and After RECOVERY FROM ACUTE UREMIA

\section{SUMMARY OF RESULTS}

In cases of chronic and acute nephritis with more than 40 per cent of normal urea clearance the plasma amino nitrogen content, determined gasometrically, was found normal, 4 to $6.5 \mathrm{mgm}$. per $100 \mathrm{cc}$.

In more advanced cases, but without uremic symptoms, the plasma amino nitrogen was sometimes normal and sometimes increased to 8 to $10 \mathrm{mgm}$. per $100 \mathrm{cc}$.

In the pre-coma stage, the plasma amino nitrogen was variable, and might change in 24 hours from practically normal to over $20 \mathrm{mgm}$. per $100 \mathrm{cc}$.

In uremic coma, the plasma amino nitrogen was found uniformly high, from 2 to 7 -fold normal.

The amino nitrogen fluctuations in the plasma were more marked than in the cells, and more regularly related to the condition of the patients. Significant variations in the plasma peptide nitrogen were not observed.

\section{CONCLUSIONS}

Elevation of plasma amino nitrogen tends to be more frequent as renal disease becomes more advanced. The correlation between fall in 
renal function and rise in plasma amino nitrogen is irregular, however; in some cases the renal clearance approaches the coma level (about 5 per cent of normal clearance) before rise in plasma amino nitrogen occurs. It appears probable, therefore, that the rise in amino acid content is not directly due to renal failure, but to a breakdown in the mechanism for metabolism of the amino acids occurring elsewhere as part of the general debacle.

\section{BIBLIOGRAPHY}

1. Becher, E., and Herrmann, E., Deutsches Arch. f. klin. Med., 1932, clxxiii, 23. Der freie und gebundene Aminostickstoff im enteiweissten Blut und Gewebe unter normalen und pathologischen Verhältnissen. IV. Der freie und gebundene Amino- $\mathrm{N}$ im enteiweissten Blut bei esentieller Hypertonie und Nierenkrankheiten.

2. Berglund, H., J. A. M. A., 1922, lxxix, 1375. Nitrogen Retention in Chronic Interstitial Nephritis and its Significance.

3. Bock, J. C., J. Biol. Chem., 1917, xxix, 191. The Amino-acid Nitrogen Content of the Blood of Various Species.

4. Desqueyroux, J., Ann. de Méd., 1923, xiii, 20. Recherches cliniques sur l'amino acidémie.

5. Feinblatt, H. M., and Shapiro, I., Arch. Int. Med., 1924, xxxiv, 690. The Amino-acid Content of Blood in Various Pathological Conditions. An Analysis of One Hundred and Sixty Determinations on One Hundred and Twenty Persons.

6. Greene, C. H., Sandiford, K., and Ross, H., J. Biol. Chem., 1924, lviii, 845. The Amino-acid Content of the Blood in Normal and Pathologic Conditions.

7. Hiller, A., and Van Slyke, D. D., J. Biol. Chem., 1922, liii, 253. A Study of Certain Protein Precipitants.

8. Hülse, W., and Franke, K., Arch. f. exp. Path. u. Pharmakol., 1929, cxliii, 257. Weitere Untersuchungen zum Chemismus der nephritischen Blutdrucksteigerung.

9. Hülse, W., and Strauss, H., Ztschr. f. d. ges. exper. Med., 1924, xxxix, 426. Zur Frage der Blutdrucksteigerung. V. Über die Wirkung höherer Eiweisspaltprodukte auf den Blutdruck und ihr Vorkommen im Blute bei hypertonischen Nierenkrankheiten.

10. Jackson, H., Jr., Sherwood, D. W., and Moore, O. J., J. Biol. Chem., 1927, lxxiv, 231. The Blood Peptide Nitrogen in Arterial Hypertension.

11. Looney, J. M., J. Biol. Chem., 1926, 1xx, 513. Blood Changes in Acute Mercuric Chloride Poisoning.

12. Losee, J. R., and Van Slyke, D. D., Am. J. M. Sc., 1917, cliii, 94. The Toxemias of Pregnancy.

13. Morse, A., Johns Hopkins Hosp. Bull., 1917, xxviii, 199. The Amino-acid Nitrogen of the Blood in Cases of Normal and Complicated Pregnancy and also in the New-born Infant.

14. Okada, S., and Hayashi, T., J. Biol. Chem., 1922, li, 121. Studies on the Amino-acid Nitrogen Content of the Blood.

15. Schlossmann, H., Ztschr. f. d. ges. exper. Med., 1925, xlvii, 487. Der Gehalt des Blutes an Aminosäuren und Polypeptiden in Schwangerschaft, Geburt und Wochenbett mit besonderer Berücksichtigung der Schwangerschaftstoxämien.

16. Schmidt, E. G., Arch. Int. Med., 1929, xliv, 351. The Amino-acid Content of the Blood in Health and in Disease. 
17. Van Slyke, D. D., J. Biol. Chem., 1929, lxxxiii, 425. Manometric Determination of Primary Amino Nitrogen and its Application to Blood Analysis.

18. Van Slyke, D. D., and Kirk, E., J. Biol. Chem., 1933 (In Press). Comparison of Gasometric, Colorimetric, and Titrimetric Determinations of Amino Nitrogen in Blood and Urine.

19. Van Slyke, D. D., Stillman, E., Mфller, E., Ehrich, W., McIntosh, J. F., Leiter, L., Mackay, E. M., Hannon, R., Moore, N. S., and Johnston, C., Medicine, 1930, ix, 257. Observations on the Courses of Different Types of Bright's Disease, and on the Resultant Changes in Renal Anatomy.

20. Witts, L., Quart. J. Med., 1929, xxii, 477. Observations on the Metabolism of Amino-acids in Health and Disease.

21. Wowsi, M., and Gelbird, J., Ztschr. f. d. ges. exper. Med., 1926, li, 518. Über die Rolle der Leber im Aminosäurenstoff wechsel.

22. Peters, J. P., and Van Slyke, D. D., Quantitative Clinical Chemistry. II. Methods. Williams and Wilkins Co., Baltimore, 1932, p. 397. 